\title{
A quantitative analysis of housing and its correlates in rural Vietnam
}

\section{Cuong Hoang Van and Yen Hai Thi Nguyen ${ }^{a^{*}}$}

${ }^{a}$ Faculty of Real-Estate and Resources Economics, National Economics University, Hanoi, Vietnam

\begin{tabular}{l}
\hline C H R O N I C L E \\
\hline Article history: \\
Received: March 12, 2020 \\
Received in revised format: \\
March 27 2020 \\
Accepted: March 29, 2020 \\
Available online: \\
April 3, 2020 \\
\hline Keywords: \\
Housing conditions \\
House type \\
Multinomial logit \\
Rural \\
Vietnam
\end{tabular}

\section{A B S T R A C T}

Using data from the 2018 Vietnam Household Living Standard Survey, the current study examines factors associated with housing conditions in rural Vietnam. We used both descriptive statistics and regression analyses. Controlling for other factors in the regression models, the study finds that households with better education and occupation were more likely to have larger sizes of housing area per person, higher value of the house and permanent houses. Also, the housing conditions are much better for the Kinh population (the ethnic majority) than that for ethnic minorities. In addition, we find that the opportunities for obtaining better housing outcomes vary largely across regions. Our research findings suggest that improving the access of ethnic minorities to education and better job are expected to improve the housing conditions.

(C) 2020 by the authors; licensee Growing Science, Canada

\section{Introduction}

Housing is widely viewed as a key health resource and plays a key role in the overall quality of life (Dunn, 2002; Evans, Wells, \& Moch, 2003; Mak, Choy, \& Ho, 2007).Thus, the quality of housing has been a main concern for both researchers and policy makers (Araujo et al., 2005; Baiden, Arku, Luginaah, \& Asiedu, 2011). Planners and policy makers try to ensure housing conditions to be served by the needs of their residents and thereby contributing to their quality of life in many countries (Addo, 2016; Hussain \& Rashid, 2015; Ibem \& Amole, 2013; Lee \& Park, 2010; Mohit, Ibrahim, \& Rashid, 2010). Vietnam has attained remarkable progress in improving the living standards of its population over the past three decades. The country had moved from one of the poorest countries in 1980s to a lower middle-income economy by the end of 2010 (Kozel, 2014). A recent report shows that about two thirds of Vietnam's population is currently defined as economically secure, consisting of the $13 \%$ who are now part the global middle-class. This group increases rapidly, rising by over $20 \%$ age points over the period 2010 to 2017 (Pimhidzai, 2018). However, Vietnam's improvement in housing conditions seems to lag behind its economic attainments. It is estimated that about $25 \%$ (approximately 4.8 million households) of the country's 24.2 million households were living in poor accommodation (Samad et al., 2015). It is reported in 2016 that there have been about $10.4 \%$ of rural population still living in temporary houses while the corresponding figure is about $2.4 \%$ in urban areas (GSO, 2016). Using the updated data from the 2018 Vietnam Household Living Standard Survey (2018 VHLSS), our study estimated that $62 \%$ and $7 \%$ of the Vietnamese rural households have lived in semi-permanent houses and temporary houses, respectively (see Table 1). While there are huge number of studies examining factors affecting household income and poverty among Vietnamese rural households (Bui, Dungey, Nguyen, \& Pham, 2014; Kang \& Imai, 2012; Nguyen, Raabe, \& Grote, 2015; Tran, 2015; Van Hoang, Tran, Nguyen, \& Nguyen, 2019), no study investigates housing and its correlates in rural Vietnam. A throughout understanding of what determining housing conditions is needed for both academic researchers and policy

* Corresponding author.

E-mail address: yennh@neu.edu.vn (Y.H. T. Nguyen)

(C) 2020 by the authors; licensee Growing Science, Canada doi: $10.5267 /$ j.msl.2020.4.009 
makers in Vietnam. The importance of the topic and the literature gap has inspired us to conduct the current research. The main objective of our study is to identify factors affecting housing conditions in rural Vietnam.

In the current study, housing conditions are mentioned in two key indicators: (i) the average housing area per person and (ii) the house types, which are the main indicators of the housing domain in Vietnam. Our econometrics analysis reveals that the level of education and occupation are major factors affecting housing conditions. Households with better education and occupation tend to have larger housing areas per person and live in permanent houses. A large gap in housing conditions is observed between ethnic minorities and the Kinh group (majority). We also discuss some policy implications that might help improve housing conditions for the poor and ethnic minorities in rural Vietnam.

\section{Data and analytical methods}

\subsection{Data}

Our study utilized a secondary dataset from the 2018 Vietnam Household Living Standard Survey, which was conducted by the General Statistical Office [GSO] of Vietnam. The survey is designed to be representative both regionally and nationally. The total household sample includes about 46,000 households, and our study uses about 30,000 rural households. The survey contains various useful information concerning socio-economic characteristics of households such as demographics, education, employment, occupation, assets, income and expenditures, and others. Especially, the survey collected information about housing conditions, including the housing area, the value of the house and various types of houses, which allows us to examine what determines the housing conditions?

\subsection{Analytical methods}

Our study employs both descriptive statistics and micro-econometric analysis. Our econometric model specification is based on the distribution of dependent variables (Wooldridge, 2016). Econometric analysis using both OLS (Eqs. (1-2)) and Multinomial logit regression (Eq. (3)) were used to examine the impact of various factors on the average housing area per person, the value of the house and the house type, respectively.

$$
\begin{aligned}
& H A_{i}=\beta_{0}+\beta_{1} X_{1 i}+\beta_{2} X_{2 i}+\beta_{3} X_{3 i}+\varepsilon_{i} \\
& H V_{i}=\beta_{0}+\beta_{1} X_{1 i}+\beta_{2} X_{2 i}+\beta_{3} X_{3 i}+\varepsilon_{i}, \\
& H T_{i}=\beta_{0}+\beta_{1} X_{1 i}+\beta_{2} X_{2 i}+\beta_{3} X_{3 i}+\varepsilon_{i}
\end{aligned}
$$

where $H A_{i}$ is the natural logarithm (log) of the average housing area per person, $H V_{i}$ is the $\log$ of the value of the house and $H T_{i}$ shows various types of houses (villa, permanent and semi-permanent houses), with the temporary house being treated as the reference group). Various independent variables were selected following previous literature (Addo, 2016; Alexiu, Ungureanu, \& Dorobantu, 2010; Hussain \& Rashid, 2015) and the sustainable livelihood framework (Scoones, 1998). Three equations use the same covariates as follows: $X_{1 i}$ is the vector of individual characteristics of household heads such as age, gender, ethnicity, education and occupation, while $X_{2 i}$ is a set of variables reflecting household characteristics, namely household size, dependency ratio and various types of lands. $X_{3 i}$ includes dummy variables for seven regions and $\varepsilon_{i}$ is an error term. Finally, $\beta_{0}, \beta_{1}, \beta_{2}$ and $\beta_{3}$ denote unknown parameters that need to be estimated. However, we did not include the income variable because this variable is often determined by education and occupation in the empirical literature (Möllers \& Buchenrieder, 2011; Tran, 2015). Thus, excluding this variable from regression models enables us to minimize the potential endogeneity problem.

\section{Results and discussions}

\subsection{Descriptive statistics}

The name, definition and measurements of both dependent and independent variables are given in Table $1.81 \%$ of the heads of household sample are Kinh people (ethnic majority). The average age of the household heads is about 52 years, $82 \%$ among them are married and $79 \%$ of the household heads are male. Regarding the highest education qualification of the heads, Table 1 shows that $20 \%$ of household heads had no education, $29 \%$ with primary education, $31 \%$ with lower secondary education while only $8 \%$ having upper secondary education, $1 \%$ with college degree and 3\% with university and higher degrees. The data also reveal that those with unskilled job accounts for $59 \%$ of the household heads, followed by those with skilled manual jobs (27\%), low skilled non-manual jobs (10\%) while only $4 \%$ with high skilled non-manual jobs. On average, each household have 3.7 members and the dependency ratio is 0.39 . The average size of annual cropland per household is $3206 \mathrm{~m}^{2}$. The corresponding figures for perennial cropland, forestland, aquaculture land and garden are $1716 \mathrm{~m}^{2}, 1863$ $\mathrm{m}^{2}, 498 \mathrm{~m}^{2}$, and $208 \mathrm{~m}^{2}$. Interestingly, Table 1 shows that only $1 \%$ of household sample live in villas, $31 \%$ with permanent households while $62 \%$ and $7 \%$ living in semi-permanent and temporary houses, respectively. Also, the average housing area per capita is about $27 \mathrm{~m}^{2}$, with the corresponding highest and smallest size being $1 \mathrm{~m}^{2}$ and $670 \mathrm{~m}^{2}$. On average, the total value of the house (as self-reported by the household head) is about 558 million Vietnam Dong (VND) ${ }^{1}$.

\footnotetext{
${ }^{1} 1$ USD equated to about 23 thousand VND in 2018.
} 
Table 1

Key characteristics of rural household sample, 2018

\begin{tabular}{|c|c|c|c|c|c|}
\hline Variable & Observation & Mean & Std. Dev. & Min & Max \\
\hline Ethnicity of household head ( $1=$ =major; $\mathrm{o}=$ =minor $)$ & 29,596 & 0.81 & 0.39 & 0 & 1 \\
\hline Age of household head (years) & 29,596 & 51.86 & 13.60 & 12 & 113 \\
\hline Marital status of household head ( $1=$ married, $0=$ otherwise $)$ & 29,596 & 0.82 & 0.38 & 0 & 1 \\
\hline Gender of household head $(1=$ male; $0=$ female $)$ & 29,596 & 0.79 & 0.41 & 0 & 1 \\
\hline \multicolumn{6}{|l|}{ Highest education level of household head } \\
\hline No education $(1=$ yes; $0=$ not $)$ & 29,596 & 0.20 & 0.40 & 0 & 1 \\
\hline Primary education $(1=$ yes; $0=$ not $)$ & 29,596 & 0.29 & 0.46 & 0 & 1 \\
\hline Lower secondary education $(1=$ yes; $0=$ not $)$ & 29,596 & 0.31 & 0.46 & 0 & 1 \\
\hline Upper secondary education ( $1=$ yes; $0=$ not $)$ & 29,596 & 0.08 & 0.28 & 0 & 1 \\
\hline College $(1=$ yes; $0=$ not $)$ & 29,596 & 0.01 & 0.10 & 0 & 1 \\
\hline University and higher ( $1=$ yes; $0=$ not $)$ & 29,596 & 0.03 & 0.17 & 0 & 1 \\
\hline \multicolumn{6}{|l|}{ Main occupation of household head } \\
\hline Unskilled job ( $1=$ yes; $0=$ not $)$ & 29,564 & 0.59 & 0.49 & 0.00 & 1.00 \\
\hline Skilled manual job ( $1=$ yes; $0=$ not $)$ & 29,564 & 0.27 & 0.45 & 0.00 & 1.00 \\
\hline Low skilled non-manual job ( $1=$ yes; $0=$ not $)$ & 29,564 & 0.10 & 0.30 & 0.00 & 1.00 \\
\hline High skilled non-manual job ( $1=$ yes; $0=$ not $)$ & 29,564 & 0.04 & 0.19 & 0.00 & 1.00 \\
\hline \multicolumn{6}{|l|}{ Household characteristics } \\
\hline Household size & 29,596 & 3.71 & 1.58 & 1.00 & 13.00 \\
\hline Dependency ratio* & 29,596 & 0.39 & 0.31 & 0 & 1 \\
\hline Annual cropland (m2) & 29,596 & 3206 & 17918 & 0 & 2700000 \\
\hline Perennial cropland (m2) & 29,596 & 1716 & 8946 & 0 & 700000 \\
\hline Forestland (m2) & 29,596 & 1863 & 11197 & 0 & 690000 \\
\hline Aquaculture land (m2) & 29,596 & 498 & 4394 & 0 & 380000 \\
\hline Garden land(m2) & 29,596 & 208 & 909 & 0.0 & 60000 \\
\hline \multicolumn{6}{|l|}{ Housing condition } \\
\hline The total value of the house ( million Vietnam dong) & 29,596 & 558 & 782 & 0.0 & 34000 \\
\hline Average housing area per person & 29,596 & 27 & 21 & 1 & 670 \\
\hline Villa $(1=$ yes; $0=$ not $)$ & 29,596 & 0.01 & 0.07 & 0.0 & 1 \\
\hline Permanent house $(1=$ yes; $0=$ not $)$ & 29,596 & 0.31 & 0.46 & 0.0 & 1 \\
\hline Semi-permanent house $(1=$ yes; $0=$ not $)$ & 29,596 & 0.62 & 0.49 & 0.0 & 1 \\
\hline Temporary house $(1=$ yes; $0=$ not $)$ & 29,596 & 0.07 & 0.26 & 0.0 & 1 \\
\hline
\end{tabular}

Source: authors' own calculation from the 2018 VHLSS. This ratio is calculated by the number of members aged under 15 and over 59 , divided by the number of members aged $15-59$

\subsection{Econometric analysis}

Table 2 reports the regression results from the housing area and value of the house models.

Table 2

Factors associated with the value and size of the house (OLS regression)

\begin{tabular}{|c|c|c|c|c|}
\hline \multirow[t]{2}{*}{ Explanatory variables } & \multicolumn{2}{|c|}{ The average housing area per person } & \multicolumn{2}{|c|}{ The total value of the house } \\
\hline & Coef & se & Coef & se \\
\hline Ethnicity & $0.19 * * *$ & $(0.016)$ & $0.76^{* * *}$ & $(0.037)$ \\
\hline Age & $0.01 * * *$ & $(0.000)$ & $0.01 * * *$ & $(0.001)$ \\
\hline Marital status & $-0.02 *$ & $(0.012)$ & $0.22 * * *$ & $(0.022)$ \\
\hline Gender & $0.05 * * *$ & $(0.011)$ & -0.01 & $(0.020)$ \\
\hline Primary education & $0.02 * *$ & $(0.008)$ & $0.04 * * *$ & $(0.016)$ \\
\hline Lower secondary education & $0.06^{* * *}$ & $(0.009)$ & $0.16^{* * *}$ & $(0.018)$ \\
\hline Upper secondary education & $0.11^{* * *}$ & $(0.013)$ & $0.27 * * *$ & $(0.023)$ \\
\hline College & $0.19 * * *$ & $(0.034)$ & $0.41 * * *$ & $(0.052)$ \\
\hline University and higher & $0.19 * * *$ & $(0.022)$ & $0.44 * * *$ & $(0.049)$ \\
\hline Skilled manual job & $0.06^{* * *}$ & $(0.009)$ & $0.21 * * *$ & $(0.018)$ \\
\hline Low skilled non-manual job & $0.15^{* * *}$ & $(0.012)$ & $0.38 * * *$ & $(0.024)$ \\
\hline High skilled non-manual job & $0.18^{* * *}$ & $(0.019)$ & $0.45^{* * *}$ & $(0.039)$ \\
\hline Dependency ratio & $-0.13 * * *$ & $(0.011)$ & $-0.34 * * *$ & $(0.020)$ \\
\hline Household size & $-0.20 * * *$ & $(0.002)$ & $0.10 * * *$ & $(0.004)$ \\
\hline Annual cropland (log) & $0.00 *$ & $(0.001)$ & $-0.01 * * *$ & $(0.003)$ \\
\hline Perennial cropland (log) & $0.01 * * *$ & $(0.001)$ & $0.01 * * *$ & $(0.003)$ \\
\hline Forestland (log) & -0.00 & $(0.002)$ & $-0.02 * * *$ & $(0.004)$ \\
\hline Aquaculture land (log) & $0.01 * * *$ & $(0.002)$ & $-0.01^{*}$ & $(0.004)$ \\
\hline Southeast & $0.07 * * *$ & $(0.017)$ & $-0.66^{* * * *}$ & $(0.038)$ \\
\hline Mekong Delta & 0.03 & $(0.023)$ & $-0.08^{*}$ & $(0.045)$ \\
\hline Central Highlands & $-0.06^{* *}$ & $(0.026)$ & $-0.34 * * *$ & $(0.062)$ \\
\hline South Central Coast & 0.02 & $(0.019)$ & $-0.55 * * *$ & $(0.046)$ \\
\hline North Central Coast & $-0.04 * *$ & $(0.019)$ & $-0.41 * * *$ & $(0.042)$ \\
\hline West Northern Mountains & 0.04 & $(0.028)$ & $-0.37 * * *$ & $(0.074)$ \\
\hline East Northern Mountains & $0.10 * * *$ & $(0.020)$ & $-0.22 * * *$ & $(0.044)$ \\
\hline Constant & $3.19 * * *$ & $(0.032)$ & $11.30 * * *$ & $(0.060)$ \\
\hline Observations & 29,564 & & 29,564 & \\
\hline R-squared & 0.360 & & 0.248 & \\
\hline
\end{tabular}


It is evident that controlling for other factors in the model, households with the head being the Kinh group, on average, have a housing area per person that is $19 \%$ higher than that among those with the head being ethnic minorities. Also the value of the house is much higher ( $76 \%$ ) for the former than that for the latter. The impact of the household heads' age on housing area and house value is hightly stistical significant but its magnitue is quite small. While the marital status of household heads has a negative and very small effect on housing area $(-2 \%)$, it does have a quite large and positive effect on the value of the house $(22 \%)$. We also find a small effect of gender effect on housing area, with the housing area per capita being $5 \%$ higher for male-headed houeholds. In both models, we find positive effects of education on the size and value of the house. Also, the effect increases with higher levels of education in both models. For instance, the average housing area per capita is $2 \%$ higher for households with the head completing primary education than those without education. Similar but larger effects are $6 \%$, $11 \%, 19 \%$ and $19 \%$ for lower secondary education, upper secondary education, college and univerisity degrees, respectively. The corresonding effect of education levels on the house value is $4 \%, 16 \%, 27 \%, 41 \%$ and $41 \%$ respectively. The finding is consistent with previous studies (Alexiu et al., 2010; Hussain \& Rashid, 2015; Kain \& Quigley, 1970) which confirmed the importance of education in housing conditions.

Table 3

Factors associated with house types (Multinomial regression model)

\begin{tabular}{|c|c|c|c|c|c|c|}
\hline \multirow[t]{2}{*}{ Explanatory variables } & \multicolumn{2}{|c|}{$\begin{array}{c}\text { Villa vs } \\
\text { temporary house }\end{array}$} & \multicolumn{2}{|c|}{$\begin{array}{l}\text { Permanent house } \\
\text { vs temporary house }\end{array}$} & \multicolumn{2}{|c|}{$\begin{array}{c}\text { Semi-permanent house vs } \\
\text { temporary house }\end{array}$} \\
\hline & RRR & SE & RRR & SE & RRR & SE \\
\hline Ethnicity & $8.02 * * *$ & $(3.300)$ & $3.92 * * *$ & $(0.553)$ & $1.63 * * *$ & $(0.186)$ \\
\hline Age & $1.03 * * *$ & $(0.008)$ & $1.04 * * *$ & $(0.003)$ & $1.03 * * *$ & $(0.002)$ \\
\hline Marital status & $1.83^{*}$ & $(0.649)$ & $1.80 * * *$ & $(0.181)$ & $1.22 * *$ & $(0.101)$ \\
\hline Gender & 1.03 & $(0.314)$ & $0.83 * *$ & $(0.078)$ & $0.85 * *$ & $(0.068)$ \\
\hline Primary education & 0.91 & $(0.234)$ & $1.13^{*}$ & $(0.081)$ & $1.23 * * *$ & $(0.075)$ \\
\hline Lower secondary education & 1.24 & $(0.306)$ & $1.70 * * *$ & $(0.139)$ & $1.48 * * *$ & $(0.109)$ \\
\hline Upper secondary education & $2.38 * * *$ & $(0.701)$ & $2.14 * * *$ & $(0.261)$ & $1.66 * * *$ & $(0.190)$ \\
\hline College & $5.42 *$ & $(5.023)$ & $5.80 * * *$ & $(3.560)$ & $4.59 * *$ & $(2.773)$ \\
\hline University and higher & $10.54 * * *$ & $(5.087)$ & $5.23 * * *$ & $(1.596)$ & $3.06 * * *$ & $(0.901)$ \\
\hline Skilled manual job & $1.60 * *$ & $(0.352)$ & $2.04 * * *$ & $(0.173)$ & $1.55 * * *$ & $(0.118)$ \\
\hline Low skilled non-manual job & $1.82 * *$ & $(0.548)$ & $2.17 * * *$ & $(0.244)$ & $1.56 * * *$ & $(0.157)$ \\
\hline High skilled non-manual job & $3.35 * * *$ & $(1.493)$ & $4.07 * * *$ & $(1.033)$ & $2.80 * * *$ & $(0.679)$ \\
\hline Dependency ratio & $0.43 * * *$ & $(0.133)$ & $0.34 * * *$ & $(0.034)$ & $0.63 * * *$ & $(0.056)$ \\
\hline Household size & $1.35^{* * *}$ & $(0.080)$ & $1.26 * * *$ & $(0.028)$ & $1.10 * * *$ & $(0.023)$ \\
\hline Annual cropland (log) & 0.96 & $(0.027)$ & 0.98 & $(0.010)$ & $1.03 * * *$ & $(0.009)$ \\
\hline Perennial cropland (log) & 1.05 & $(0.032)$ & 1.01 & $(0.013)$ & $1.04 * * *$ & $(0.010)$ \\
\hline Forestland $(\log )$ & 0.98 & $(0.042)$ & $0.97 *$ & $(0.015)$ & 1.00 & $(0.014)$ \\
\hline Aquaculture land (log) & 1.05 & $(0.041)$ & 1.00 & $(0.016)$ & $0.96 * * *$ & $(0.012)$ \\
\hline Southeast & $0.02 * * *$ & $(0.005)$ & $0.01 * * *$ & $(0.001)$ & $0.09 * * *$ & $(0.018)$ \\
\hline Mekong Delta & $0.06^{* * *}$ & $(0.027)$ & $0.02 * * *$ & $(0.007)$ & $0.33 * * *$ & $(0.076)$ \\
\hline Central Highlands & $0.02 * * *$ & $(0.013)$ & $0.02 * * *$ & $(0.005)$ & $0.19 * * *$ & $(0.048)$ \\
\hline South Central Coast & $0.13 * * *$ & $(0.066)$ & $0.09 * * *$ & $(0.029)$ & 1.27 & $(0.373)$ \\
\hline North Central Coast & $0.06^{* * *}$ & $(0.026)$ & $0.08 * * *$ & $(0.019)$ & $0.30 * * *$ & $(0.073)$ \\
\hline West Northern Mountains & $0.06^{* * *}$ & $(0.046)$ & $0.10 * * *$ & $(0.029)$ & $0.22 * * *$ & $(0.061)$ \\
\hline East Northern Mountains & $0.12 * * *$ & $(0.045)$ & $0.09 * * *$ & $(0.020)$ & $0.17 * * *$ & $(0.037)$ \\
\hline Constant & $0.01 * * *$ & $(0.008)$ & 1.42 & $(0.439)$ & $3.81 * * *$ & $(1.070)$ \\
\hline Pseudo R2 & & & & & & \\
\hline Prob $>$ chi 2 & & & & & & \\
\hline Observations & & & & & & \\
\hline
\end{tabular}

Note: Robust standard errors in parentheses. ${ }^{* *} \mathrm{p}<0.01,{ }^{*} \mathrm{p}<0.05,{ }^{*} \mathrm{p}<0.1$ RRR: relative risk ratios.

Source: authors' own calculation from the 2018 VHLSS.

As given in Table 3, the Multinomial logit estimates are reported in the form of he relative risk ratios (RRR). The results confirm the key role of education in living better houses. For instance, the RRR of living in a permanent house is 1.13 times highter for households with the head having primary education. The corresonding figures are 1.70, 2.14, 5.8 and 5.23 times higher for lower secondary education, upper secondary education, college and university. In all three models, we find that occupation of household heads plays a decisive role in securing better housing conditions. The average housing area per person and the value of the housse is $18 \%$ and $45 \%$ higher for households with the heads having skilled non-maunal jobs than for those with the heads being unskilled workers. The RRR of living in villas, permanent and semi-permanent houses (relative to temporary houses) is 3.35, 4.07 and 2.80 times higher those with the heads being high skilled non-manual workers than those with their heads being unskilled workers. Notably, Table 3 indicates that households in the ethnic majority (Kinh population) have RRR that is 8.02, 3.92 and 1.63 times higher to live in villas, permanent and semi-permanent houses than for those in ethnic minorities. Finally, we also find evidence that housing conditions vary across regions. Specifically, with the same individual and household characteristics, households living in the Southeast and East Northern Mountains regions, on average, tend to larger housing areas per person while those in the Central highland and North Central Coast tend to have smaller housing areas per person than those living in the Red River Delta (the reference group). Interestingly, we find that the value of the house is much lower in all regions than that in the Red River Delta. Also, households living in other region are more likely to live in temporary houses than those living in the Red River Delta. 


\section{Conclusion and policy implications}

The main aim of the current study was to examine housing and its correlates in rural Vietnam. It has been estimated that $32 \%$ of the rural household sample lived in permanent houses, while $62 \%$ living in semi-permanent houses and $7 \%$ with temporary houses. The average housing area per capita is about $27 \mathrm{~m}^{2}$ and the average value of the house is about 558 million VND. Our econometric analysis has found a number of key factors affecting housing conditions in rural Vietnam. First, households with better education attain higher quality of housing conditions, including the housing area per person, permanent houses and higher values of the house. Second, these housing conditions are also better for households with better occupations. These findings, combined together, show the importance of human capital in securing better housing outcomes. We find a large gap in housing quality between ethnic minority households and Kinh households in rural Vietnam. The former always have lower level of education and occupation than do the latter in Vietnam (Tran, 2015). The findings imply that improving the access of the ethnic minorities to education can help them not only move out of poverty but also improve their housing conditions. Notably, we find housing quality varies largely across regions. Households living in the Red River Delta tend to living in permanent households than those in other regions. This suggests that the opportunities for attaining better housing outcomes might be affected by some socio-economic-regional factors. This implies that housing policies should be designed accounting for differences in the regional context. Investigating the reason for this difference also offers an interesting topic for future research.

\section{Acknowledgement}

This research is part of the project number BĐKH.41/16-20.

\section{References}

Addo, I. A. (2016). Assessing residential satisfaction among low income households in multi-habited dwellings in selected low income communities in Accra. Urban Studies, 53(4), 631-650.

Alexiu, T. M., Ungureanu, D., \& Dorobantu, A. (2010). Impact of education in terms of housing opportunities. ProcediaSocial Behavioral Sciences, 2(2), 1321-1325.

Araujo, N. P., Camarini, R., Souza-Formigoni, M. L. O., Carvalho, R. C., Abílio, V. C., Silva, R. H., . . Frussa-Filho, R. (2005). The importance of housing conditions on behavioral sensitization and tolerance to ethanol. Journal of pharmacology Biochemistry Behavior, 82(1), 40-45.

Baiden, P., Arku, G., Luginaah, I., \& Asiedu, A. B. (2011). An assessment of residents' housing satisfaction and coping in Accra, Ghana. Journal of Public Health, 19(1), 29-37.

Bui, A. T., Dungey, M., Nguyen, C. V., \& Pham, T. P. (2014). The impact of natural disasters on household income, expenditure, poverty and inequality: evidence from Vietnam. Applied Economics, 46(15), 1751-1766.

Dunn, J. R. (2002). Housing and inequalities in health: a study of socioeconomic dimensions of housing and self reported health from a survey of Vancouver residents. Journal of Epidemiology Community Health, 56(9), 671-681.

Evans, G. W., Wells, N. M., \& Moch, A. (2003). Housing and mental health: a review of the evidence and a methodological and conceptual critique. Journal of Social Issues, 59(3), 475-500.

GSO. (2016). Section 8: Housing, electricity, water and sanitation facilities. In GSO (Ed.), The results of Vietnam Household Living Standard Survey. Hanoi, Vietnam: General Statistical Office of Vietnam.

Hussain, I., \& Rashid, J. (2015). Determinants of the Quality of Housing in Poor and Non-Poor Households. Gomal University Journal of Research, 31(2), 87-98.

Ibem, E. O., \& Amole, D. J. S. i. r. (2013). Residential satisfaction in public core housing in Abeokuta, Ogun State, Nigeria. Social Indicators Research, 113(1), 563-581.

Kain, J. F., \& Quigley, J. M. (1970). Measuring the value of housing quality. Journal of the American Statistical Association, $65(330), 532-548$.

Kang, W., \& Imai, K. (2012). Pro-poor growth, poverty and inequality in rural Vietnam. Journal of Asian Economics, 23(5), 527-539.

Kozel, V. (2014). Well begun but not yet done: Progress and emerging challenges for poverty reduction in Vietnam. Hanoi, Vietnam: The World Bank.

Lee, E., \& Park, N.-K. (2010). Housing satisfaction and quality of life among temporary residents in the United States. Housing and Society, 37(1), 43-67.

Mak, S. W., Choy, L. H., \& Ho, W. K. (2007). Privatization, housing conditions and affordability in the People's Republic of China. Habitat International, 31(2), 177-192.

Mohit, M. A., Ibrahim, M., \& Rashid, Y. R. (2010). Assessment of residential satisfaction in newly designed public low-cost housing in Kuala Lumpur, Malaysia. Habitat international, 34(1), 18-27.

Möllers, J., \& Buchenrieder, G. (2011). Effects of rural non-farm employment on household welfare and income distribution of small farms in Croatia. Quarterly Journal of International Agriculture, 50(892-2016-65199), 217-235.

Nguyen, L. D., Raabe, K., \& Grote, U. (2015). Rural-urban migration, household vulnerability, and welfare in Vietnam. World Development, 71(1), 79-93. 
Pimhidzai, O. (2018). Climbing the ladder: poverty reduction and shared prosperity in Vietnam. Washington, D.C: World Bank Group.

Samad, T., Hoang, H., Brhane, M., Mcvitty, J., Nguyen, H., Harrison, D., \& Tran, T. J. W., DC: World Bank Group. (2015). Vietnam-Affordable Housing: A Way Forward. Hanoi, Vietnam: the World Bank.

Scoones, I. (1998). Sustainable rural livelihoods: a framework for analysis. Retrieved from Brighton, UK:

Tran, T. Q. (2015). Socio-economic determinants of household income among ethnic minorities in the North-West Mountains, Vietnam. Croatian Economic Survey, 17(1), 139-159.

Van Hoang, C., Tran, T. Q., Nguyen, Y. H. T., \& Nguyen, K. D. (2019). Is Land Ownership a Key Factor in the Choice of Livelihood in the Mekong Delta, Vietnam? Human Ecology, 47(5), 681-691.

Wooldridge, J. M. (2016). Introductory econometrics: A modern approach: Nelson Education.

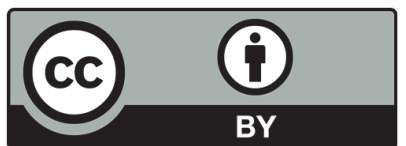

(C) 2020 by the authors; licensee Growing Science, Canada. This is an open access article distributed under the terms and conditions of the Creative Commons Attribution (CC-BY) license (http://creativecommons.org/licenses/by/4.0/). 